\title{
Androgen Receptor Expression in Human Ovarian and Uterine Tissue of Long Term Androgen-Treated Transsexual Women
}

\author{
SAVI CHADHA, MD, PHD, THIERRY D. PACHE, MD, PHD, \\ FRANS J. M. HUIKESHOVEN, MD, PHD, \\ ALBERT O. BRINKMANN, MD, PHD, \\ AND THEODORUS $H$. VAN DER KWAST, MD, PHD
}

\begin{abstract}
Androgen receptor (AR) modulation in human uteri and ovaries of long term androgen-treated transsexual female patients was investigated. Androgen receptor expression was evaluated immunohistochemically in the ovaries of 11 and the endometria and myometria of six androgen-treated transsexual female patients. This was compared with $\mathbf{A R}$ expression in the ovaries and uteri of premenopausal and postmenopausal women not receiving treatment and in 10 ovaries of female patients with polycystic nvarian disease (PCOD). In the normal ovaries germinal epithelium, granulosa cells of antral follicles, corpus luteum, and thecal and stromal cells exhibited moderate AR expression. The more intense and uniform staining of ovarian stroma of female transsexual patients and those of patients with PCOD compared with ovarian stroma of normal controls was most remarkable. This similarity in histology and distribution of ARs supports the hypothesis that PCOD is an androgen-mediated disorder. Immunostaining for ARs was only occasionally detectable in the uteri of premenopausal and postmenopausal women. In contrast, myometrial and endometrial stroma of the uteri of female transsexual patients displayed an intense and diffuse nuclear immunostaining, but glandular epithelia remained unstained. Western blot analysis of the ovaries and uterine myometrial tissue samples from transsexual female patients confirmed the presence of the 110-kd AR molecule. Because the androgen treatment of some transsexual female patients was discontinued 6 weeks before they underwent hysterosalpingo-oophorectomy, our data indicate a stable and persistent androgen-induced up-regulation of AR expression in ovaries. HUM PATHOL 25:11981204. Copyright $(\mathcal{C} 1994$ by W.B. Saunders Company
\end{abstract}

Women with female gender dysphoria (transsexualism) who prepare for gender reassignment receive prolonged androgen treatment while awaiting reassignment surgery. This group of patients receiving a high dose of exogenous androgen over a prolonged period of time provides a unique and ethically acceptable opportunity to study the morphological and endocrinologic effects of androgen on ovary and uterus. Histological changes in the genital tracts of transsexual female patients who received long term androgen therapy were described by Miller et $a l^{1}$ and Futterweit et al. ${ }^{2}$ Histological examination showed marked changes in cervical epi-

From the Departments of Pathology, Endocrinology and Reproduction, and Gynecology and Obstetrics, Erasmus University Rotterdam, the Netherlands; and the Department of Gynecology and Obstetrics, Centre Hospitalier Universitaire Vaudois, Lausanne, Switzerland. Accepted for publication April 4, 1994.

Key words: female genital tract, androgen receptor, immunohistochemistry, transsexual, polycystic ovarian disease.

Address correspondence and reprint requests to Savi Chadha, MD, PhD, Department of Pathology, Erasmus University Rotterdam, PO Box 1738, 3000 DR, Rotterdam, the Netherlands

Copyright (C) 1994 by W.B. Saunders Company

$0046-8177 / 94 / 2511-0010 \$ 5.00 / 0$ thelia and a variable degree of endometrial atrophy. ${ }^{1,2}$ The ovaries showed an increased number of follicular cysts and an occasional corpus luteum. The finding of similar histological changes in ovaries of women exposed to exogenous androgens and in patients with polycystic ovarian disease (PCOD) suggests that the morphological changes observed in the latter indeed result from excess androgens. ${ }^{3}$ It is not clear whether these androgens mediate effects by direct interaction with androgen receptors (AR) in the target cell or after their conversion into estrogens by estrogen receptors.

The production of a monoclonal antibody designated F39.4 specific for human ARs has permitted us to employ a simple immunohistochemical method for light microscopic visualization of ARs in normal human tissues, including testis, prostate, and cervix. ${ }^{4} \mathrm{~A}$ limited number of studies have described the localization of ARs in human endometrium. ${ }^{5-7}$ Hild-Petito et al $^{8}$ demonstrated the presence of ARs in the follicle and corpus luteum of primate ovary. Recently, the immunohistochemical localization of ARs in human ovary was studied at various stages of the menstrual cycle and follicular development. ${ }^{9}$ We also showed immunohistochemically the presence of ARs in ovarian carcinomas and in granulosa cell tumors of ovary. ${ }^{10}$ The immunohistochemical findings from the latter studies make it likely that in human ovary androgens may influence follicular recruitment and growth by a direct interaction of androgens with ARs. ${ }^{11}$

This study was designed to investigate whether exposure of ovarian tissue to androgens results in altered AR expression in the different cell types. For that purpose AR expression was evaluated in normal ovaries and compared with that in ovaries of female transsexual patients treated with large doses of androgen and in ovaries of patients with PCOD. The histological changes observed in endometria of androgen-treated women could be the result of either a direct interaction of androgens with ARs or an indirect interaction by way of estrogens produced by aromatization of androgens. To explore the possibility of the former we examined the presence of ARs in endometria and myometria of uteri obtained from androgen-treated female transsexual patients.

\section{MATERIALS AND METHODS}

\section{Patients}

Thirtcen ovaries were obtaincd from 11 fcmalc-to-malc transsexuals who underwent hysterectomy and bilateral oo- 
phorectomy. Mean age at the time of surgery was 25 years (range, 18 to 35 years). Menstrual cycles were regular in all but three women before androgen therapy was started. Testosterone treatment was given for a mean period of 21 months (range, 11 to 72 months) before surgery. One normal ovary frozen at autopsy, four paraffin-embedded ovaries from premenopausal women 31 to 46 years old, and seven ovaries from postmenopausal women who underwent surgery for nonendocrine reasons provided a total of 12 normal ovaries as controls. Ten ovaries from patients 20 to 49 ycars old with documented PCOD, including one ovary frozen at autopsy, also were available.

The following testosterone preparations were administered before surgery (Table 1): (1) $250 \mathrm{mg}$ of Sustanon ( 30 $\mathrm{mg}$ of testosterone propionate, $60 \mathrm{mg}$ of $\mathrm{T}$ phenylpropionate, $60 \mathrm{mg}$ of $\mathrm{T}$ isohexanoate, and $100 \mathrm{mg}$ of $\mathrm{T}$ undecanoate; Organon. Oss, The Netherlands) was given intramuscularly once every second week for a mean period of 25 months (range, 12 to 72 months) to three women; (2) 120 to 160 $\mathrm{mg} / \mathrm{d}$ of Andriol (10 $\mathrm{mg}$ of $\mathrm{T}$ undecanoate; Organon) was given orally for a mean period of 15 months (range, 12 to 21 months) to seven women; and (3) $125 \mathrm{mg} / \mathrm{d}$ of dihydrotestosterone (Vrij Universiteit Hospital Pharmacy, gel preparation) was given to one woman for 11 months. Data on serum hormonal levels were available for eight of these 11 patients (Table 1); in all but one patient testosterone treatment was discontinued 6 weeks before surgery. Serum testosterone levels normalized in these women.

Uterine specimens were available from six female-to-male transsexual patients to whom testosterone treatment was administered for a period of 14 to 96 months until surgery. Their ages ranged from 22 to 37 years (average, 27 years). In addition, uterine specimens were obtained from 10 premenopausal women 32 to 51 years old and seven postmenopausal women 56 to 78 years old undergoing hysterectomy for nonendocrinological reasons. Specimens were transported immediately after surgery to the laboratory. Half of each ovary and $0.5-\mathrm{cm}^{3}$ samples of endometrial and myometrial tissue were snap-frozen in liquid nitrogen.

\section{Antibody}

The mouse monoclonal antibody F39.1 (Sanbio, Uden, the Netherlands) specific for human AR was raised against an oligopeptide corresponding to amino acids 301 to 320 in the N-terminal domain of human AR. ${ }^{12.13}$ This antibody is able to detect the presence of ARs by a simple immunohistochemical method. Previously we showed that the immunore- activity of F39.4 with ARs is not influenced by ligand-induced transformation of the AR molecule. ${ }^{14}$ No significant cross reactivity of F39.4 was seen with human progesterone, estrogen, or glucocorticoid receptors. ${ }^{4,13}$

\section{Immunohistochemistry}

Cryostat sections, 5- $\mu$ thick, air dried, and subsequently fixed in $4 \%$ buffered formalin for 10 minutes, were dehydrated in chilled methanol and acetone. After washing in phosphate-buffered saline (PBS) at PH 7.4, the slides were incubated with $5 \%$ nonimmune rabbit serum (Dakopatts, Glostrup, Denmark) diluted in PBS to block nonspecific antibody binding and immediately incubated overnight with a 1:10,000 dilution of F39.4 ascitic fluid in PBS. To compare immunoreactivity of different ovarian samples sections were incubated with different titers of F39.4. Titration of the antibody F39.4 was done by 10-fold dilutions of the original dilution $(1: 10,000)$ in PBS. Immunoreactivity was visualized with a two-step peroxidase antiperoxidase technique as described previously. ${ }^{4}$ Hydrogen peroxide and diaminobenzidine were used as substrates. In negative controls the primary antibody was replaced by an irrelevant monoclonal antibody or PBS. A semiquantitative estimation of $A R$ positivity was performed by scoring the intensity of staining as focally positive $( \pm)$. positive $(+)$, or intensely positive $(+t)$.

Paraffin sections, 5- $\mu$ thick, were cut and mounted on 3aminopropyltriethoxysilane-coated slides (Sigma, St Louis, $\mathrm{MO}$ ) to prevent detachment resulting from the high temperature present during antigen retrieval treatment. The sections were placed in a $60^{\circ} \mathrm{C}$ oven for overnight drying. After deparaffinization and rehydration endogenous peroxidase activity was blocked with $3 \% \mathrm{H}_{2} \mathrm{O}_{2}$ in methanol. Sections then were placed in a plastic box containing $200 \mathrm{~mL}$ of $0.01 \mathrm{~mol} / \mathrm{L}$ citric acid monohydrate (Merck, Darmstadt, Germany) adjusted to pH 6.0 with $\mathrm{NaOH}$ and heated in a microwave oven (Miele M696, Vianen, the Netherlands) for $3 \times 5$ minutes at $700 \mathrm{~W}$, during which time the fluid level was checked cvery 5 minutes and filled when necessary. The sections were allowed to cool to room temperature and were rinsed with PBS. Then they were preincubated for 15 minutes at room temperature with nonimmune goat serum (Dakopatts, Glostrup, Denmark) diluted in PBS (1:10). Next the primary antibody F39.4, diluted 1:5000 in PBS, was applied for overnight incubation at $4^{\circ} \mathrm{C}$. After rinsing in PBS the sections were subsequently incubated with biotinylated goat antimouse antibody (Dakopatts) diluted in PBS (1:400) for 30 minutes in streptavidin-biotinperoxidase complex (Strept-ABC; Dakopatts) for 30 minutes,

TABLE 1. Pretreatment and Posttreatment Serum Hormonal Levels From Eight Female Transsexual Patients

\begin{tabular}{|c|c|c|c|c|c|c|c|c|c|c|c|c|}
\hline \multirow{2}{*}{$\begin{array}{c}\text { Patient } \\
\text { No. }\end{array}$} & \multirow{2}{*}{$\begin{array}{l}\text { Date of } \\
\text { Birth }\end{array}$} & \multirow{2}{*}{$\begin{array}{c}\text { Start of } \\
\text { Androgen } \\
\text { Treatment/ } \\
\text { Date of } \\
\text { Surgery }\end{array}$} & \multirow{2}{*}{$\begin{array}{l}\text { Androgen } \\
\text { Treatment }\end{array}$} & \multicolumn{2}{|c|}{ L.H $(\mu / \mathrm{L})$} & \multicolumn{2}{|c|}{ FSH $(\mu / \mathbf{L})$} & \multicolumn{2}{|c|}{$\begin{array}{c}\text { E2 (pmol/ } \\
\text { L) }\end{array}$} & \multicolumn{2}{|c|}{$\begin{array}{c}\text { TE (nmol/ } \\
\text { L) }\end{array}$} & \multirow[b]{2}{*}{$\operatorname{PR}(\mu / \mathrm{L})$} \\
\hline & & & & Pre† & Post $\ddagger$ & Pre & Post & Pre & Post & Pre & Post & \\
\hline $1 *$ & $08-03-63$ & $07-88 / 12-89$ & Andriol & 7.7 & 0.1 & 5.5 & 2.5 & - & 181 & - & 2.7 & 0.27 \\
\hline $2 *$ & $05-11-63$ & $08-85 / 07-90$ & Andriol & 3.5 & - & 2.5 & - & 640 & - & 1.8 & 3.6 & 0.32 \\
\hline 3 & $09-14-63$ & $12-88 / 05-90$ & Andriol & 3.3 & 10.5 & 11.9 & 3.8 & - & & 2.7 & 1.7 & 0.26 \\
\hline 4 & $06-28-67$ & $08-88 / 02-90$ & Andriol & - & 9.6 & - & 9.4 & - & 159 & - & 1.9 & - \\
\hline 5 & $06-10-55$ & $06-76 / 05-90$ & Testoviron & - & 一 & - & - & - & - & - & - & - \\
\hline 6 & $12-18-86$ & $01-89 / 12-89$ & Andriol & 4.5 & 9.3 & 13.7 & 8.9 & - & 618 & $<1$ & 1.2 & 0.52 \\
\hline 7 & $03-22-55$ & $05-84 / 05-90$ & Sustanon & 4.7 & 1.6 & 5.4 & 6.6 & - & 344 & - & 30.1 & 0.14 \\
\hline 8 & $03-29-68$ & $08-89 / 06-90$ & $\mathrm{DHT}$ & 8.7 & 0.4 & 3.0 & 1.2 & 231 & 56 & 2.2 & 0.8 & 0.31 \\
\hline
\end{tabular}

Abbreviations: LH, luteinizing hormone; FSH, follicle stimulating hormone; E2, estradiol; TE, testosterone; PR, progesterone

* Pretreatment cycle irregular. Androgen treatment: Andriol $40 \mathrm{mg}$ two tablets twice daily; Sustanon $250 \mathrm{mg} / \mathrm{IM} / 2 \mathrm{wk}$.

t Pretreatuent level.

\$ Posttreatment level. 
and in 3,3'-diaminobenzidine tetrahydrochloride (Fluka, Basel, Switzerland) for 7 minutes. Between each incubation step the sections were rinsed three times in PBS. Negative controls were included, replacing F39.4 antibody with PBS for all the tissues investigated. Mayer's hematoxylin was used for nuclear counterstaining.

\section{Western Blot Analysis}

Western blot analysis was performed on ovarian and uterine tissues of androgen-treated female transsexual patients confirming the presence of human ARs. Frozen tissue specimens were pulverized under liquid nitrogen. One hundred milligrams of the resulting powder was suspended in $200 \mu \mathrm{L}$ of buffer $(40 \mathrm{mmol} / \mathrm{I}$ of Tris, $1 \mathrm{mmol} / \mathrm{I}$, of ethylenediaminetetraacetic acid, $10 \%[\mathrm{v} / \mathrm{v}]$ glycerol, $0.08 \%[\mathrm{w} / \mathrm{v}]$ sodium docecylsulfate [SDS], $10 \mathrm{mmol} / \mathrm{L}$ of dithiothreitol [DHT], $0.5 \%$ $[\mathrm{w} / \mathrm{v}]$ deoxycholate, and $1 \%[\mathrm{v} / \mathrm{v}]$ Triton $\mathrm{X} 100)$ in the presence of inhibitors of proteolytic breakdown $[0.6 \mathrm{mmol} / \mathrm{L}$ phenyl-methyl-sulfonyl fluoride], $0.5 \mathrm{mmol} / \mathrm{L}$ Bacitracin, and $0.25 \mathrm{mmol} / \mathrm{L}$ of leupeptine). After lysis for 20 minutes on ice the suspension was centrifuged for 10 minutes at $1,700 \mathrm{~g}$. The supernatant was stored at $-80^{\circ} \mathrm{C}$ until use. From $200 \mu \mathrm{L}$ of tissue lysate and $50 \mu \mathrm{L}$ of LNCaP cytosol ARs were immunoprecipitated with AR-specific monoclonal antibody F39.4 complexed to goat-antimouse immunoglobulin G-agarose, followed by SDS-polyacrylamide gel electrophoresis, as described previously. ${ }^{15}$ Western blotting was performed with monoclonal antibody F39.4. The procedure for protein detection was described in detail previously. ${ }^{4,15}$

\section{RESULTS}

\section{Histomorphological Features of Ovaries and Uterine Tissue From Female Transsexual Patients}

Transsexual ovaries from female transsexual patients were grossly enlarged and displayed an increased number of cystic follicles and atretic follicles (Fig 1); ovarian cortices were collagenized and thicker (Fig 2). Theca interna hyperplasia and luteinization were uniformly observed in cystic follicles. Stromal hyperplasia accompanied frequently by clusters of luteinized cells was a constant finding.

Histological examination of the uteri of female

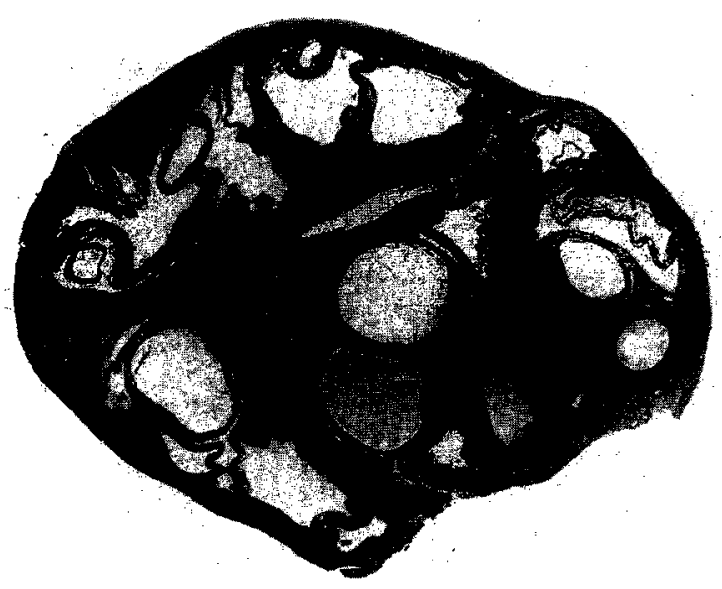

FIGURE 1. Section of ovary of female transsexual patient showing multiple cystic atretic follicles. (Hematoxylin-eosin (HE) stain: original magnification $\times 4$.) transsexual patients showed inactive endometria. The glands were small and tubular, mostly lined by a single layer of cuboidal or low columnar epithelium, and a few glands displayed slight stratification. No mitoses were seen. In two cases endometria showed atrophy with small, tubular, rather sparse glands. Endometrial stroma showed no significant changes. In one of these cases tubal metaplasia was present. No endometrial samples showed any evidence of secretory activity. The myometria in the uteri of female transsexual patients were histologically unremarkable.

\section{Androgen Receptor Expression in Normal Ovarian Tissue}

In the seven ovaries from postmenopausal women the germinal (coelomic) epithelia and the epithelial lining of inclusion cysts showed strong nuclear reactivity for ARs. The underlying stroma exhibited a patchy staining reaction for ARs (Fig 3). Cryostat sections of the ovarian tissue obtained at autopsy as well as the four normal paraffin-embedded ovaries from premenopausal women showed positive nuclear staining of granulosa cells and a small proportion (10\%) of stromal cclls (Fig 4). The corpus lutea demonstratcd positive nuclear staining for ARs, but some selective cytoplasmic staining also was observed. The same cytoplasmic staining was found in control sections using a nonspecific antibody indicating that the cytoplasmic staining of lutein cells was nonspecific. Germinal epithelia and stroma always were negative in the control sections.

\section{Androgen Receptor Expression in Ovarian} Tissue of Fermale Transsexual Patients and Patients With PCOD

In 13 ovaries obtained from 11 female transsexual patients ovarian stroma showed a diffuse and intense nuclear AR expression. Granulosa and thecal cells of the follicle cysts present in 11 ovarian samples exhibited strong nuclear reactivity as well (Fig 5). Ovarian tissue from one frozen ovary and nine paraffin-embedded ovaries from patients with PCOD showed similar findings with intense nuclear staining of granulosa and thecal cells and diffuse, intense staining of ovarian stroma (Fig 6). Data on AR expression in ovaries of normal controls and patients with PCOD are listed in Table 2.

To substantiate our impression (judging from the intensity of immunohistochemical staining) that ovaries from female transsexual patients had higher levels of ARs than did ovaries from normal postmenopausal women, titration was performed with F39.4 in three ovaries from normal controls and three ovaries from female transsexual patients. In contrast to the ovaries from normal postmenopausal women in which the staining was heterogeneic (with variation in intensity and a lower percentage of positive cells), virtually all ovarial stromal cells from female transsexual patients remained positive even at the greatest dilution of 1:32,000 (Table 2). The intensity of staining of stromal cells from female transsexual patients diminished with higher dilutions showing a dilution response and proving that the staining of stromal cells was not an artifact. 


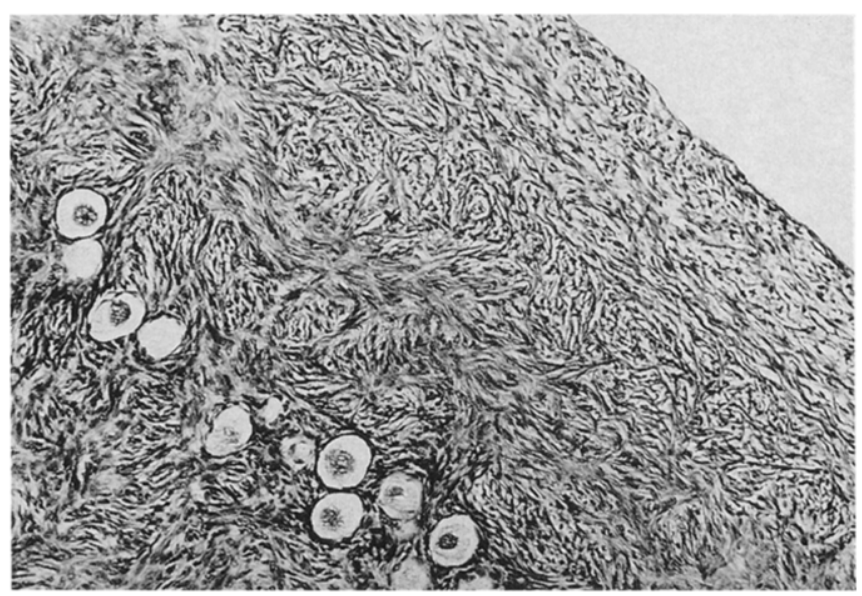

FIGURE 2. Thickened collagenized tunica albuginea in ovary of female transsexual patient. (HE stain; original magnification $\times 380$.)

\section{Androgen Receptor Expression in Uterine} Tissue of Female Transsexual Patients and Normal Women

Myometrial and endometrial stromal cells from all six uteri of female transsexual patients displayed an intense nuclear reaction for ARs. In contrast, endometrial glandular epithelia remained completely negative (Figs 7 and 8). Uteri of premenopausal women tested generally were negative for $\mathrm{AR}$ in myometrium and endometrium, except in two cases in which a focal and faint staining of endometrial stromal cells and of smooth muscle cells of myometrium was seen.

Three uteri of postmenopausal women exhibited a moderately intense AR expression in myometrium, and in one of these endometrial stroma also contained focal areas with a faint nuclear reactivity for F39.4 (Table 3). None of the uterine tissues studied displayed staining of blood vessel walls.

\section{Western Blot Analysis}

With F39.4 a 110-kd doublet was observed in uterine tissues of female transsexual patients corresponding

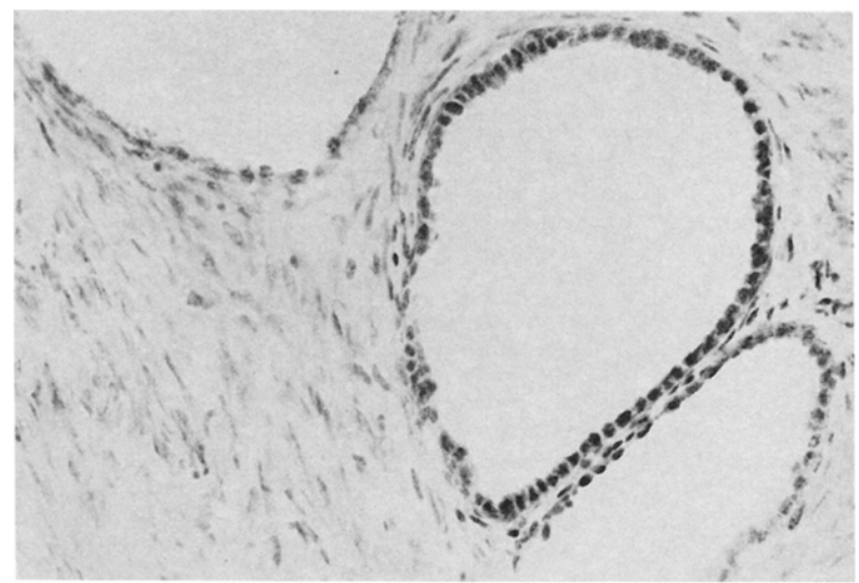

FIGURE 3. Normal ovary. Epithelial lining of inclusion cyst shows strong nuclear reactivity for AR; stroma shows patchy staining reaction. (No nuclear counterstain; original magnification $\times 380$.)

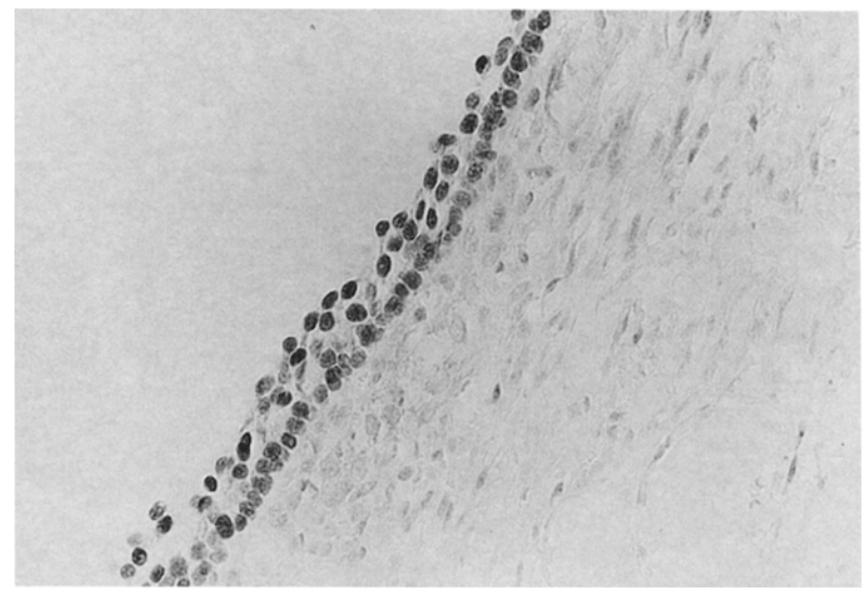

FIQURE 4. Normal ovary. Granulosa cells of antral follicle exhibit strong positivity for AR. (No nuclear counterstain: original magnification $\times 380$.)

to the well established molecular weight of the phosphorylated and nonphosphorylated variants of AR (Fig 9). ${ }^{16}$ In the uterine tissue of a nontreated premenopausal woman this $110 \mathrm{kd}$ doublet also was detectable. The large low molecular weight band in the Western blot of the uteri of androgen-treated female transsexual patient represents degradation products. The strong variation in degradation of the 110-kd AR molecule precludes a reliable quantitation of AR on the basis of Western blot analysis.

\section{DISCUSSION}

To date a limited number of studies have described the presence of $\mathrm{ARs}$ in human endometrium. ${ }^{5-7}$ In our study we detected the presence of ARs in human endometrium and myometrium and compared the localization of AR in normal human ovary with that in the ovaries of female transsexual patients receiving large doses of androgen.

Cytosolic detection of ARs in nuclear fractions of

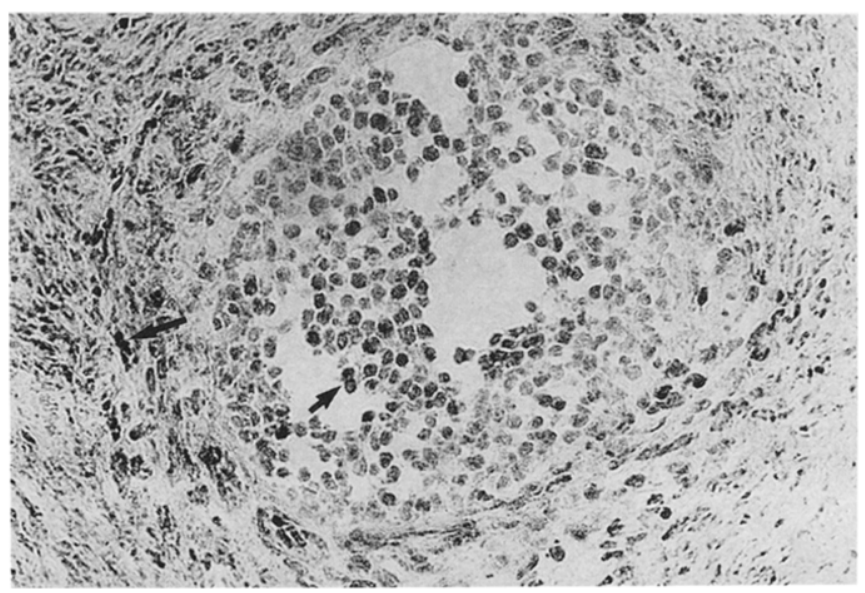

FIOURE 5. Ovary from female transsexual patient. Granulosa cells (short arrow), thecal cells (long arrow), and stroma show intense nuclear AR expression. (No nuclear counterstain; original magnification $\times 380$.) 


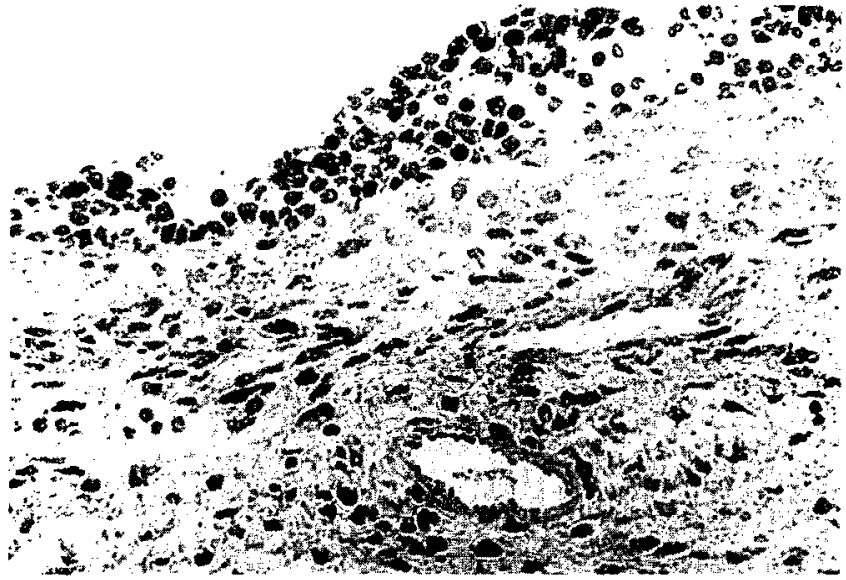

FIGURE 6. Ovary from patient with PCOD showing intense nuclear staining of granulosa cells and stroma. (No nuclear counterstain: original magnification $\times 380$.)

rat ovaries by classical binding methods was reported by Schreiber et al ${ }^{17}$ and Schreiber and Ross. ${ }^{18}$ Our results on human ovarian tissue showing the presence of ARs in granulosa-thecal cells, stroma, and corpus luteum confirm those of Horie et $\mathrm{al}^{9}$ in human ovary. In the ovaries of rhesus monkeys ARs were observed in germinal epithelium, stromal fibroblasts, granulosa cells, and corpus luteum. ${ }^{8}$ The results of these studies are consistent with the concept that androgens interacting with ARs play an essential role in follicular growth and maturation, atresia, and luteinization in an either autocrine or paracrine manner. They are thus consistent with the hypothesis that androgens could play a direct role in ovarian function regulation via a receptor-mediated mechanism..$^{11,19}$

Distinct from ARs, estrogen receptors are selectively localized in germinal epithelium and not in antral follicle, corpus luteum, or stromal cells of normal ovary. Progesterone receptors have been detected in stromal and thecal cells and not in granulosa cells. ${ }^{9}$ Ovaries of the female transsexual patients exhibited an intense AR expression by the granulosa-thecal cells of the follicles as well as by stroma. The presence of $\mathrm{AR}$ molecules in the ovaries and uterine tissues of androgen-treated female transsexual patients was further substantiated by Western blot analysis showing the characteristic 110kd doublet in tissue homogenates. Our titration study

TABLE 2. Androgen Receptor Immunohistochemical Expression in Ovaries of Normal Controls and Female Transsexual Patients

\begin{tabular}{lcc} 
& \multicolumn{1}{c}{ Ovarian Stroma } & Granulosa Cells \\
\hline $\begin{array}{l}\text { Normal ovary } \\
\text { Ovary from female } \\
\text { transsexual } \\
\text { patient }\end{array}$ & $\pm^{*}(5 / 12)+:+(7 / 12)$ & $+(12 / 12)$ \\
$\begin{array}{l}\text { Ovary from } \\
\text { patient with }\end{array}$ & $++(13 / 13)$ & $+(3 / 10) ;++(7 / 10)$ \\
PCOD & $+(1 / 10) ;++(9 / 10)$ & $+(1 / 10) ;++(9 / 10)$ \\
\hline
\end{tabular}

$* \pm,+,++$, intensity of staining.

+ Fraction of examined cases

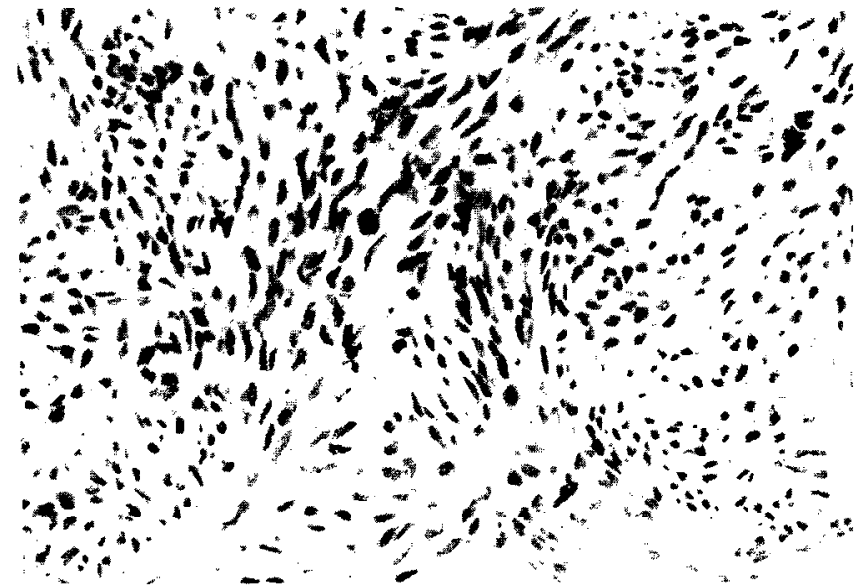

FIOURE 7. Uterine tissue from female transsexual patient. Myometrium displays an intense nuclear reaction for $A R$ ( $H E$ counterstain; original magnification $\times 380$.)

demonstrated that AR expression by ovarian stromal cells in the ovaries of androgen-treated female transsexual patients is more uniform and more intense than it is in the ovaries of nontranssexual (premenopausal and postmenopausal) women. We also demonstrated in 10 ovaries from women with PCOD that the stromal cells exhibited a similar diffuse and intense AR staining as is the case in the ovaries of androgen-treated female transsexual patients. The hyperplasia of stromal cells in the ovaries of androgen-treated female transsexual patients and the ovaries of patients with PCOD provides an additional argument for androgen-mediated functional effects in human ovary. In PCOD stromal hyperplasia may be a consequence of either prolonged exposure to elevated androgens or of hypersensitivity of the stromal cells to androgens. The increased presence of ARs in the hyperplastic stroma of ovaries of patients with PCOD and in ovaries of androgen-exposed female transsexual patients implies a functional role of $A K$ in this morphological change.

It should be notcd that in most of thesc female transsexual patients androgen therapy was discon-

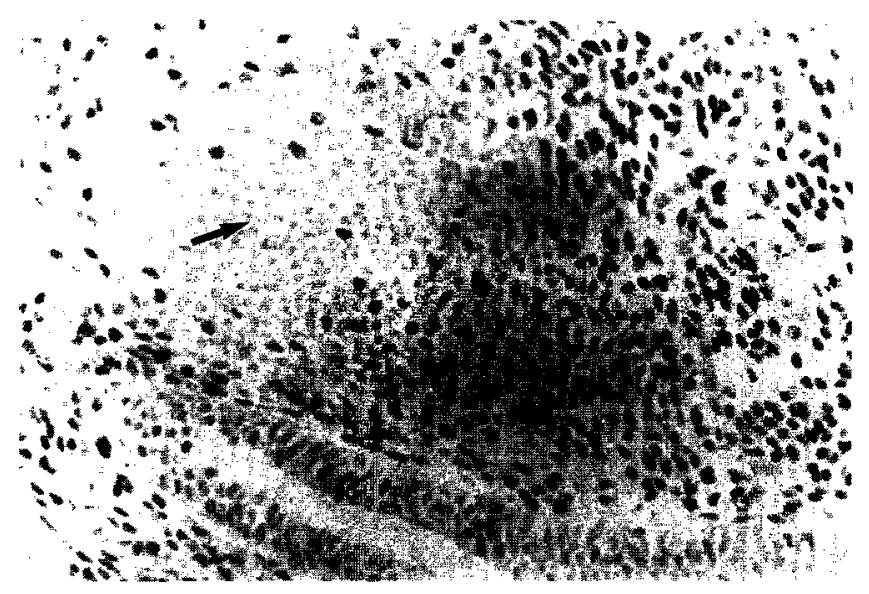

FICURE 8. Uterine tissue from female transsexual patient. Endometrial stroma cells stain strongly positive for AR. Note the negative glandular epithelium and lymph follicie (arrow). (No nuclear counterstain; original magnification $\times 380$.) 
tinued 6 weeks before surgery, resulting in low testosterone levels (Table 1). Apparently the androgen-induced upregulation of ARs in ovarian stroma is quite stable and persists for a considerable time after removal of the inducing agent.

Ruizeveld et al $^{4}$ studied AR expression immunohistochemically in several human tissues and showed AR localization in male sex organs, vagina, and cervix, although in a small series of uterine tissues no immunoreactivity for ARs was detectable. In this larger series of uteri of premenopausal and postmenopausal women focal AR expression occasionally was detected with immunohistochemistry in human endometrial stroma and myometrium. Western blot analysis of untreated uterine tissue confirmed the presence of a 110-kD AR molecule but did not allow quantitation. The observed increase in AR expression in the ovaries, and particularly in the endometria and myometria of female transsexual patients receiving long-term androgen therapy, may be the result of androgen-mediated up-regulation of AR expression. Considering the high turnover of endometrial stromal cells, the possibility of replacement of ARnegative stromal cells by AR-positive stromal cells should be considered as well. Because the turnover of myometrial as well as ovarian stroma is low, the observed androgen-induced intense positivity with anti-AR must be a consequence of androgen-induced AR upregulation within the same cells.

Autoregulation of AR expression has been described in a few experimental models. ${ }^{15,214-22}$ In a human prostate carcinoma cell line androgen ablation has been shown to down-regulate AR expression. ${ }^{15}$ Moreover, several investigators showed in animal models that androgens up-regulate AR expression. ${ }^{90.22}$ Autoregulation of ARs may occur at the transcriptional or posttranscriptional level. Studies performed by Kemppainen et $\mathrm{al}^{203}$ in monkey kidney cells (COS cells) transfected with AR gene constructs demonstrated that AR half-life is increased in the presence of androgen. This suggests a posttranscriptional regulation mechanism. Nonetheless, so far no evidence is available on human AR stabilization by hormones under physiological conditions.

Androgen therapy in female transsexual patients leads to a striking contrast in its effects on ovarian, endometrial, and myometrial tissues. In the ovaries of the fenuale transsexual patients the presence of numerous cystic follicles is associated with hyperplasia of ovarian stromal and thecal cells. In contrast, the endometria

TABLE 3. Immunohistochemical Analysis of Androgen Receptor in Endometria and Myometria of Female Transsexual Patients and Premenopausal and Postmenopausal Women

\begin{tabular}{lcr}
\hline & $\begin{array}{c}\text { Endometria } \\
\text { (Stroma) }\end{array}$ & Myometria \\
\hline Premenopausal women & $2 * \pm \dagger(\mathrm{n}=7)^{+}$ & $2 \pm(\mathrm{n}=7)$ \\
Postmenopausal women & $1 \pm(\mathrm{n}=7)$ & $3+(\mathrm{n}=7)$ \\
Female transsexual patients & $6++(\mathrm{n}=6)$ & $\mathbf{6}++(\mathrm{n}=6)$ \\
\hline
\end{tabular}

* Number of cases positive.

$1 \pm,+,++$, internsity of staining.

\pm Number of cases tested

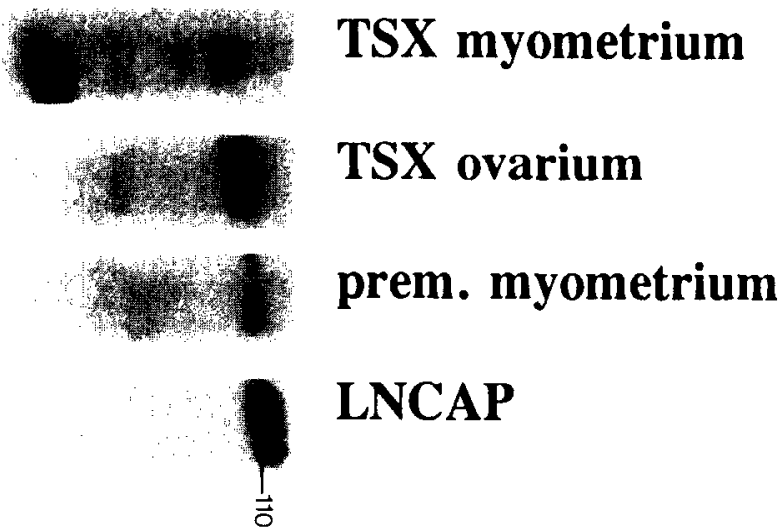

FICURE 9. Western blot analysis of lysates of myometrial and ovarian tissue of an androgen-treated female transsexual patient (lanes 1 and 2) and of myometrial tissue of a nontreated premenopausal woman (lane 3). Nuclear fraction of LNCaP (lane 4) served as a positive control. The dense low molecular weight band in lane 1 represents a 50-kd degradation product of AR. TSX, transsexual; prem, premenopausal.

of female transsexual patients showed an inactivation or even atrophy of the glandular compartment. but stromal cells were not significantly affected. The myometria of female transsexual patients examined by us showed no apparent atrophy or hyperplasia. However, functional changes in myometrium may be induced by androgens. Thus, Roy et $\mathbf{a l}^{24}$ demonstrated a severalfold increase in $\mathrm{NAD}^{+}$-dependent uterine prostaglandin 15 hydroxydehydrogenase in androgen-treated female transsexual patients.

The lack of ARs in glandular epithelial cells suggests that the glandular changes are not a consequence of direct interaction of androgen with these epithelial cells. It remains to be established whether the androgen effect on endometrial glands is mediated by a paracrine effect on stromal cells. It is not likely that the inactivation of endometrial glands is caused by an altered exposure to hypophysis-derived gonadotropic hormones. Previous studies ${ }^{25}$ showed that androgen treatment does not substantially alter serum levels of follicle stimulating hormone or luteinizing hormone. The variety in morphological effects of androgens on the female genital tract implies that other regulatory proteins also determine the outcome of the interaction of androgens with ARs in these organs.

Acknouledgment. We thank C.C.J. vian Vroonhoven, P.J.A. Janssen, M.C.T. Verleun-Mooijman, and F.L. van der Panne for technical assistance and $M$. Hanegraaff for preparing the manuscript.

\section{REFERENCES}

1. Milley N, Bédard YC, Conter NB, et al: Histological change: in the genital tract in transsexual women following androgen therapy Histopathology 10:661-669, 1986

2. Futterweit W, Deligdisch $\mathrm{I}$ : Histopathological effects of exogenously administered testosterone in 19 female 10 male transsexuals J Clin Endocrinol Metab 62:16-21, 1986)

3. Pache TD, Chadha S, Gooren IJG, et al: Ovarian morphology in long-term androgen-treated female to male transsexuals. A human 
model for the study of polycystic ovarian syndrome? Histopathology 19:445-451, 1991

4. Ruizeveld de Winter JA, Trapman JA, Vermey M, et al: Androgen receptor expression in human tissues. An immunohistochemical study. J Histochem Cytochem 39:927-936, 1991

5. Horie K, Takakura K, Imai K, et al: Immunohistochemical localisation of androgen receptor in the human endometrium, decidua, placenta and pathological conditions of the endometrium. Hum Reprod 7:1461-1466, 1992

6. Tamaya T, Murakami T, Okada H: Concentrations of steroid receptors in normal human endometrium in relation to the day of the menstrual cycle. Acta Obstet Gynecol Scand 65:195-198, 1986

7. Muechler EK: The androgen receptor of the human endometrium. Endocr Res 13:69-84, 1987

8. Hild-Petito S, West NB, Brenner RM, et al: Localization of androgen receptor in the follicle and corpus luteum of the primate ovary during the menstrual cycle. Biol Reprod 44:561-568, 1991

9. Horie K, Takakura K, Fujiwara $\mathrm{H}$, et al: Immunohistochemical localization of androgen receptor in the human ovary throughout the menstrual cycle in relation to oestrogen and progesterone receptor expression. Hum Reprod 7: 2:184-190, 1992

10. Chadha S, Rao BR, Slotman BJ, et al: An immunohistochemical evaluation of androgen and progesterone receptors in ovarian tumors. HUM PATHOL 24:90-95, 1993

11. Daniel SAJ, Armstrong DT: Androgens in the ovarian microenvironment. Semin Reprod Endocrinol 4:89-100, 1986

12. Trapman J, Ris-Stalpers C, Van der Korput JAGM, et al: The androgen receptor: Functional structure and expression in transplanted human prostate tumors and prostate tumor cell lines. J Steroid Biochem Mol Biol 37:837-842, 1990

13. Zegers ND, Claassen E, Neelen C, et al: Epitope prediction and confirmation for the human androgen receptor: Generation of monoclonal antibodies for multi-assay performance following the synthetic peptide strategy. Biochem Biophys Acta 1973:23-32, 1991

14. Veldscholte J, Berrevoets CA, Zegers ND, et al: Hormone induced dissociation of the androgen receptor-heat-shock protein complex: Use of a new monoclonal antibody to distinguish transformed from nontransformed receptors. Biochemistry 32:7422-7430, 1991
15. Ruizeveld de Winter JA, Van Weerden W, Faber PW, et al: Regulations of androgen receptor expression in the human heterotransplantable prostate carcinoma PC-82. Endocrinology 131:30453050,1992

16. Van Laar JH, Bolt-De Vries J, Zegers ND, et al: Androgen receptor heterogeneity and phosphorylation in human LNCaP cells. Biochem Biophys Res Commun 166:193-200, 1990

17. Schreiber JR, Reid R, Ross GT: A receptor-like testosteronebinding protein in ovaries from estrogen-stimulated hypophysectomized immature female rats. Endocrinology 98:1206-1213, 1976

18. Schreiber JR, Ross GT: Further characterisation of a rat ovarian testosterone receptor with evidence of nuclear translocation. Endocrinology 99:590-596, 1976

19. Hillier SG, De Zwart FA: Evidence that granulosa cell induction/activation by follicle-stimulating hormone is an androgen receptor-regulated process in vitro. Endocrinology 109:1303-1305, 1981

20. Quarmby VE, Yarbrough WG, Lubahn DB, et al: Autologous down-regulation of androgen receptor messenger ribonucleic acid. Mol Endocrinol 4:22-28, 1990

21. Shan LX, Rodriguez MC, Janne OA: Regulation of androgen receptor protein and $\mathrm{mRNA}$ concentrations by androgens in rat ventral prostate and seminal vesicles and in human hepatoma cells. Mol Endocrinol 4:1636-1646, 1990

22. Krongrad A, Wilson CM, Wilson JD, et al: Androgen increases androgen receptor protein while decreasing receptor $\mathrm{mRNA}$ in LNCaP cells. Mol Cell Endocrinol 76:79-88, 1991

23. Kemppainen JA, Lane MV, Sar M, et al: Androgen receptor phosphorylation, turnover, nuclear transport and transcription activation. J Biol Chem 267:968-974, 1992

24. Roy AC, Sen DK, Ratnam SS: Evidence for severalfold more activity of $\mathrm{NAD}^{+}$-dependent uterine prostaglandin 15-hydroxydehydrogenase in transsexual than in non-transsexual women. Prostaglandins 37:171-180, 1989

25. Scheele F, Spijkstra JJ, Hompes PGA, et al: The effect of 6 weeks of testosterone treatment on pulsatile luteinizing hormone secretion in engonadal female-to-male transsexuals. Fertil Steril 55:608-611, 1991 